\title{
Environmental Predictors of Pathogenic Vibrios in South Florida Coastal Waters
}

\author{
Koske Yamazaki and Nwadiuto Esiobu*
}

\author{
Biological Sciences Department, Charles E. Schmidt College of Science, Florida Atlantic University, 3200 College \\ Avenue, Davie, Florida 33314, USA
}

\begin{abstract}
In 2007, diseases caused by Vibrio vulnificus and other Vibrio species became nationally notifiable in the United States because of the potential severity of bloodstream infections. Direct contact of open wound with seawater and the ingestion of contaminated oysters are the principal modes of transmission. Presently, no clear environmental predictors of oyster contamination are known. This study is the first to report an apparent association between rainfall and Vibrio counts at five South Florida beaches. Using multiple regression and ANOVA, the relationship between Vibrio populations and various environmental factors were examined. Vibrio counts ranged from $135 \mathrm{CFU} / 100 \mathrm{~mL}$ at Hollywood Beach to $186,000 \mathrm{CFU} / 100 \mathrm{~mL}$ at North Miami Beach. Vibrio vulnificus and parahemolyticus were detected (less than $1 \%$ of all identified isolates) at two and four beaches respectively. Temperature and rainfall dates were the most significant correlates of the incidence of pathogenic Vibrio species.
\end{abstract}

Keywords: Vibrio prevalence, environmental factors, rainfall, pathogenic vibrios, coastal beaches.

\section{INTRODUCTION}

Prior to 2007, the United States lacked a national surveillance system for Vibrio vulnificus infections. Although only about 900 cases were reported between 1988 and 2006 in the Gulf coastal states [1], the potential severity and high mortality of bloodstream infections have launched these pathogens into the limelight. The dearth of information on the ecological dynamics of $V$. vulnificus in response to environmental variables makes it difficult to predict transmission risks via oyster consumption.

Vibrio species are ubiquitous to marine, estuarine, and freshwater environments [2]. Utilizing existing wounds [3, 4] and ingestion of contaminated water or seafood [5] as their major routes of infection, vibrios can cause enteric diseases, wound infections, and bloodstream invasion in vulnerable individuals [6,7]. According to Howard and Bennett [6], prevalence of marine Vibrio infections (foodborne and waterborne) in Florida ranks among the highest in the world, and swimmers in coastal waters of the Gulf of Mexico are also affected. Water quality standards established by the U.S. Environmental Protection Agency (USEPA) [8] for monitoring recreational waters (using Escherichia coli and enterococci as indicators) do not always correlate with the incidence or infectious doses of pathogenic vibrios [9-13]. In addition, Bonilla et al., [14] noted that total coliform and fecal coliform numbers were not perfect predictors of diarrheal diseases of swimmers in marine waters. Knowledge of the prevalence of pathogenic Vibrio species and the environmental factors that affect their numbers in recreational beaches is important for risk

*Address correspondence to this author at the Biological Sciences Department, Charles E. Schmidt College of Science, Florida Atlantic University, 3200 College Avenue, Davie, Florida 33314, USA; Tel: (954) 236 1128; Fax: (954) 236 1099; E-mail: nesiobu@fau.edu assessment and control of disease transmission via oyster beds.

Here, we report the detection and relative abundance of pathogenic Vibrio species in five South Florida beaches. The influence of salinity, rainfall, and water temperature on the occurrence of these bacteria was also evaluated.

\section{MATERIALS AND METHODS}

Seawater from five popular beaches on the southeast coast of Florida (Pompano Beach at Atlantic Blvd., Fort Lauderdale Beach at Las Olas Blvd., Hollywood Beach at Johnson St., North Miami Beach between $182^{\text {nd }}$ and $183^{\text {rd }}$ Streets., and South Beach at 9th St.) was sampled every two weeks, from October $9^{\text {th }}$ to November $19^{\text {th }} 2007$, between 7:30 am and 11:30 am. At each sampling site, the water was obtained in duplicate from about $30 \mathrm{~cm}$ below the water surface in $100-\mathrm{mL}$ sterile sample bottles. Water temperature and salinity were measured at each site. The rainfall data at each location was obtained from District Daily Rainfall Report of South Florida Water Management District (www.sfwmd.gov/curre/3_rainfall.html).

Total cultivable Vibrio (TCV) counts were determined by the membrane filtration technique [15] using $45 \mu \mathrm{m}$-pore size membranes (Millipore, Waltham, MA) on Difco TM Thiosulfate-Citrate-Bile-Sucrose (TCBS) Agar plates (Becton Dickinson, Franklin Lakes, NJ). Plates were incubated at room temperature $\left(22-24^{\circ} \mathrm{C}\right)$ for 24 hours. Characteristic Vibrio colonies were cqunted and expressed as colony forming units (CFU) $100 \mathrm{~mL}^{-1}$ beach water sample.

Characteristic Vibrio colonies on TCBS Agar were isolated and purified on modified Tryptic Soy Agar (TSA) (Becton Dickinson, Cockeysville, MD) - 5\% pancreatic digest of casein, $0.5 \%$ soy bean meal, $3 \% \mathrm{NaCl}, 0.15 \%$ $\mathrm{MgSO}_{4}$, and $1.5 \%$ Agar. The isolates were definitively identified with Biolog GN Microplate system (Biolog Inc., 
Hayward, CA) according to manufacturer's instructions except that overnight cultures of the strains were grown on the amended TSA. Statistical analyses, including one-way ANOVA, regression analysis, and Pearson correlation (Minitab 13, Minitab Inc., State College, PA) were used to test the relationship between the various factors measured.

\section{RESULTS AND DISCUSSION}

Table 1 displays the dynamics of Vibrio bacteria in the recreational beaches studied. Vibrio alginolyticus, $V$. carchariae (harveyi) and $V$. species were the most prevalent in all beaches studied. Notably, V. vulnificus and $V$. parahaemolyticus, which are typically the most frequently encountered pathogenic vibrios, were rarely present on the sample dates and detected at two and four beaches respectively. They were mainly found together at Pompano and North Miami beaches, at very low levels (1\% of the total Vibrio population). On three of four sampling dates, $V$. vulnificus occurred at North Miami Beach- a phenomenon that may be linked to nutrient status (unpublished data), beach topography, and run-off.
Such low densities of $V$. vulnificus and $V$. parahaemolyticus at the studied beaches suggest these pathogenic vibrios may reside in other niches along Florida's vast coastline. It is possible that the majority of Vibrio sources in Florida are derived from the West coast, along the Gulf of Mexico. In a US study surveying non-foodborne marine Vibrio infections from 1997-2006, states along the Gulf Coast reported the largest number of cases (57\%), followed by those in the Atlantic region (24\%) [16].

Despite the low occurrence of pathogenic vibrios at the studied Florida beaches, their mere presence can easily translate into a risk of foodborne infection as they tend to accumulate in filter-feeding organisms such as oysters and clams [6]. It is also worth noting that the risk of nonfoodborne infections by marine vibrios may greatly be influenced by individual immune status and exposure to open wounds.

A negative correlation (Pearson correlation $=-0.540$, $\mathrm{P}=0.014$ ) was found between total Vibrio counts and total coliforms (results not shown). Temporal variation at a given

Table 1. Occurrence of Vibrio Species in Five South Florida Beaches

\begin{tabular}{|c|c|c|c|c|c|c|c|c|c|}
\hline $\begin{array}{l}\text { Sampling } \\
\text { Date }\end{array}$ & $\begin{array}{c}\text { Beach } \\
\text { Location }\end{array}$ & 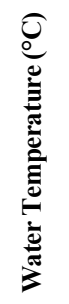 & 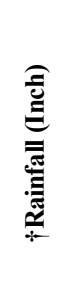 & 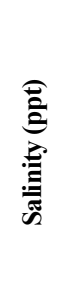 & 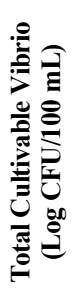 & 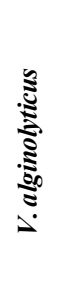 & 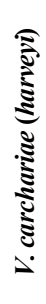 & 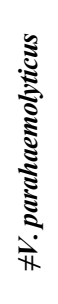 & 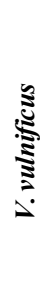 \\
\hline \multirow{5}{*}{ Oct. 11} & Pompano (Atlantic Blvd.) & 28.0 & 0.35 & 32.2 & 3.38 & ++ & + & $*$ & nd \\
\hline & Ft. Lauderdale (Las Olas Blvd.) & 28.0 & 0.42 & 32.0 & 3.01 & ++ & + & nd & nd \\
\hline & Hollywood (Johnson St.) & 28.0 & 1.06 & 32.5 & 2.13 & ++ & + & nd & nd \\
\hline & North Miami (182nd and 183rd St.) & 27.5 & 0.48 & 32.5 & 2.43 & ++ & + & nd & $*$ \\
\hline & South Beach (9th St.) & 27.0 & 0.22 & 33.0 & 2.23 & ++ & + & nd & nd \\
\hline \multirow{5}{*}{ Oct. 23} & Pompano (Atlantic Blvd.) & 26.0 & 0 & 32.0 & 3.88 & ++ & + & $*$ & $*$ \\
\hline & Ft. Lauderdale (Las Olas Blvd.) & 26.5 & 0 & 32.8 & 5.09 & ++ & + & $*$ & nd \\
\hline & Hollywood (Johnson St.) & 26.8 & 0.02 & 32.9 & 4.12 & ++ & + & nd & nd \\
\hline & North Miami (182nd and 183rd St.) & 26.5 & 0.46 & 31.1 & 4.28 & ++ & + & nd & nd \\
\hline & South Beach (9th St.) & 26.0 & 0 & 31.1 & 4.32 & ++ & + & nd & nd \\
\hline \multirow{5}{*}{ Nov. 6} & Pompano (Atlantic Blvd.) & 25.0 & 0.10 & 31.0 & 4.06 & ++ & + & $*$ & nd \\
\hline & Ft. Lauderdale (Las Olas Blvd.) & 24.5 & 0 & 31.0 & 4.46 & ++ & + & $*$ & nd \\
\hline & Hollywood (Johnson St.) & 25.0 & 0 & 31.0 & 4.32 & ++ & + & nd & nd \\
\hline & North Miami (182nd and 183rd St.) & 24.0 & 0 & 32.5 & 5.27 & ++ & + & $*$ & $*$ \\
\hline & South Beach (9th St.) & 25.0 & 0 & 32.5 & 4.49 & ++ & + & nd & nd \\
\hline \multirow{5}{*}{ Nov. 20} & Pompano (Atlantic Blvd.) & 24.5 & 0 & 33.0 & 4.42 & ++ & + & $*$ & nd \\
\hline & Ft. Lauderdale (Las Olas Blvd.) & 24.0 & 0 & 32.5 & 4.57 & ++ & + & $*$ & nd \\
\hline & Hollywood (Johnson St.) & 24.0 & 0 & 32.5 & 4.02 & ++ & + & nd & nd \\
\hline & North Miami (182nd and 183rd St.) & 23.0 & 0 & 34.5 & 4.54 & ++ & + & $*$ & * \\
\hline & South Beach (9th St.) & 23.5 & 0 & 34.0 & 4.18 & ++ & + & * & nd \\
\hline
\end{tabular}

+ Source of rainfall data: www.sfwmd.gov/curre/3 rainfall.html; ++ = More than $70 \%$ of recovered vibrios; $+=$ Less than $20 \%$ of recovered vibrios; $*=$ Less than $1 \%$ of recovere vibrios; $\neq=V$. parahaemolyticus and other Vibrio species; nd $=$ Not detected. 


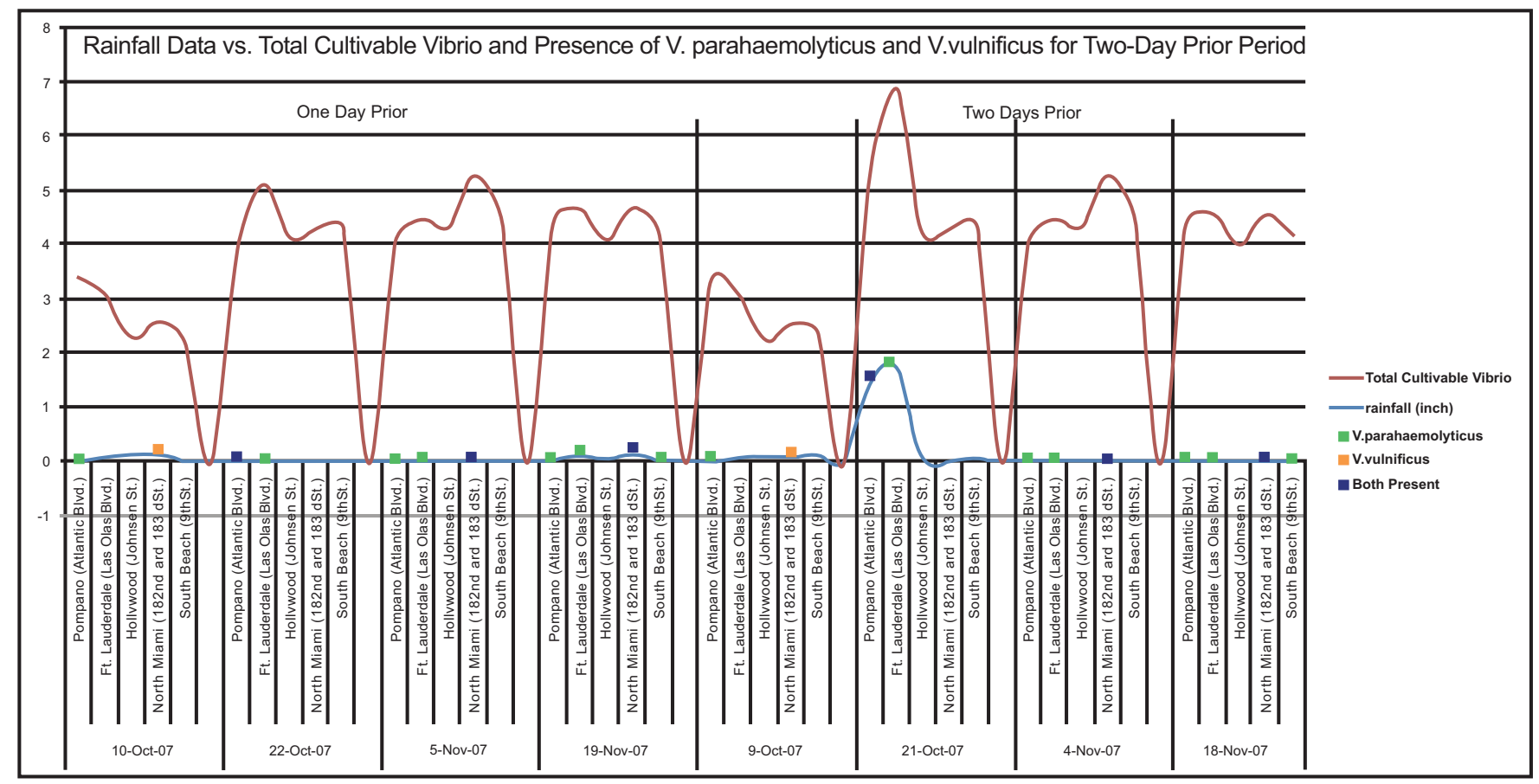

Fig. (1). Occurrence of total cultivable and pathogenic vibrios in five public beaches of South Florida plotted against rainfall data from one and two days prior to sampling.

site was highly significant $(\mathrm{F}=33.26, \mathrm{P}=0.001)$. Several possible factors that might influence the densities of Vibrio bacteria were selected and examined by regression analysis.

Three rainfall time-points including: two days prior to sampling (day -2); one day before (day -1); and the day of sampling (day 0), were analyzed against CFU/100mL of seawater at each location and sampling date. Remarkably, the level of vibrios in the coastal waters demonstrated a significant positive correlation with the occurrence of rainfall two days prior (day -2) to sampling $\left(\mathrm{R}^{2}=26.8 \%\right.$, $\mathrm{F}=6.60, \mathrm{P}=0.019$ ) (Fig. 1). All other combinations of rainfall and bacterial density showed no relationship. Consequential decrease in salinity, increase in turbidity, change in chlorophyll $a$ levels [17], and nutrient accumulation during rainfall runoff may serve as plausible explanations of the observed trend.

Water temperature remained optimal [18] for the survival of vibrios during the study $\left(23-28^{\circ} \mathrm{C}\right)$ (Table 1). In a Florida study surveying the cases of invasive infections due to marine Vibrio bacteria between January 1979 and December 1991 , $80 \%$ of patients developed invasive marine Vibrio infections during the summer months of May-October [6], which coincide with increased temperatures and rainfall. The prime climatic conditions for marine Vibrio survival at Florida's beautiful beaches could contribute to the elevated incidence of Vibrio infections relative to other coastal regions in the United States. Other factors, such as depths of sampling sites and tidal levels are also known to significantly affect the concentration of Vibrio spp [13].

\section{CONCLUSION}

Total cultivable Vibrio counts in the beaches fluctuated remarkably with environmental conditions such as rainfall, especially occurring two days prior to sampling. Levels of the pathogenic vibrios, $V$. vulnificus and $V$. parahaemolyticus, could not be predicted by total Vibrio counts. Their incidence also remained very low at the beaches where they were detected. Routine monitoring of South Florida beaches for Vibrio numbers does not appear to be warranted given the sporadic occurrence of the pathogens. Occasional assessment of risk after rainfall may, however, be necessary, particularly in areas where oysters are harvested for consumption.

\section{ACKNOWLEDGEMENTS}

Mrs. Corine M. Stinson is acknowledged for her contributions in revising and editing this manuscript.

\section{CONFLICT OF INTEREST}

There are no known conflicts of interest in this study.

\section{REFERENCES}

[1] National Center for Emerging and Zoonotic Infectious Diseases. Vibrio vulnificus. Atlanta (GA): Centers for Disease Control and Prevention (CDC); 2009 Nov [cited 26 Jan 2012]. Available from: http://www.cdc.gov/nczved/divisions/dfbmd/diseases/vibriov/.

[2] Montanari MP, Pruzzo C, Pane L, Colwell RR. Vibrios associated with plankton in a coastal zone of the Adriatic sea (Italy). FEMS Microbiol Ecol 1999; 29: 241-7.

[3] Cerdà-Cuéllar M, Jofre J, Blanch AR. A selective medium and specific probe for detection of Vibrio vulnificus. Appl Environ Microbiol 2000; 66: 855-9.

[4] Chiou CS, Hsu SY, Chiu SI, Wang TK, Chaos CS. Vibrio parahaemolyticus serovar O3:K6 as cause of unusually high incidence of food-borne disease outbreaks in Taiwan from 19961999. J Clin Microbiol 2000; 38: 4621-5.

[5] Blake PA, Merson MH, Weaver RE, Hollis DG, Heublein PC. Disease caused by a marine Vibrio: clinical characteristics and epidemiology. N Engl J Med 1979; 300:1-5.

[6] Howard RJ, Bennett NT. Infections caused by halophilic marine Vibrio bacteria. Ann Surg 1993; 217: 525-31. 
[7] Hlady WG, Klontz KC. The epidemiology of Vibrio infections in Florida, 1981-1993. J Infect Dis 1996; 173: 1176-83.

[8] U.S. Environmental Protection Agency (USEPA). Test methods for Escherichia coli and enterococci in water by the membrane filter procedure. EPA-600/4-85/076. Cincinnati (OH): U.S. Environmental Protection Agency, Environmental Monitoring and Support Laboratory. 1985; 1-25.

[9] Kaneko T, Colwell RR. Ecology of Vibrio parahaemolyticus in Chesapeake Bay. J Bacteriol 1973; 113: 24-32.

[10] Colwell RR, Kaper J, Joseph SW. Vibrio cholerae, Vibrio parahaemolyticus, and other vibrios: occurrence and distribution in Chesapeake Bay. Science 1977; 198: 394-6.

[11] Oliver JD, Warner RA, Cleland DR. Distribution and ecology of Vibrio vulnificus and other lactose-fermenting marine vibrios in coastal waters of the southeastern United States. Appl Environ Microbiol 1982; 44: 1404-14.

[12] Shiaris MP, Rex AC, Pettibone GW, et al. Distribution of indicator bacteria and Vibrio parahaemolyticus in sewage-polluted sediments. Appl Environ Microbiol 1987; 53: 1756-61.
[13] Koh EGL, Huyn JH, LaRock PA. Pertinence of indicator organisms and sampling variables to vibrio concentrations. Appl Environ Microbiol 1994; 60: 3897-900.

[14] Bonilla TD, Nowosielski K, Cuvelier M, et al. Prevalence and distribution of fecal indicator organisms in South Florida beach sand and preliminary assessment of health effects associated with beach sand exposure. Mar Pollut Bull 2007; 54: 1472-82.

[15] Fujioka RS. Indicators of marine recreational water quality. In: Hurst CJ, Knudsen GR, McInerney MJ, Stezenbach LD, Walters MV, Eds. Manual of Environmental Microbiology. Washington, DC: ASM Press 1997; pp. 176-83.

[16] Dechet AM, Yu PA, Koram N, Painter J. Nonfoodborne Vibrio infections: an important cause of morbidity and mortality in the United States, 1997-2006. Clin Infect Dis 2008; 46: 970-6.

[17] Johnson CN, Flowers AR, Noriea NF 3rd, et al. Relationships between environmental factors and pathogenic vibrios in the northern gulf of Mexico. Appl Environ Microbiol 2010; 76: 707684.

[18] Motes ML, DePaola A, Cook DW, et al. Influence of water temperature and Salinity on Vibrio vulnificus in Northern Gulf and Atlantic coast oysters. Appl Environ Microbiol 1998; 64: 1459-65.

(C) Yamazaki and Esiobu; Licensee Bentham Open.

This is an open access article licensed under the terms of the Creative Commons Attribution Non-Commercial License (http://creativecommons.org/licenses/by$\mathrm{nc} / 3.0 /$ ) which permits unrestricted, non-commercial use, distribution and reproduction in any medium, provided the work is properly cited. 